\title{
OPERATION OF THE CONSENT DECREE IN THE MOTION PICTURE INDUSTRY $\dot{\dagger}$
}

Since November 20, 1940 the motion picture industry has been operating under the terms of a consent decree, the result of an anti-trust action designed to eliminate some of the industry's alleged monopolistic elements. ${ }^{1}$ The operations of the industry divide basically into three stages: producing companies lease their product through nationwide distributors to numeruus exhibitors who show the films in their theatres. However, in the process of industry consolidation eight companies, defendants in the anti-trust suit, have cornered the production end of the industry and have largely gained control also of the distributing field, making the once independent distributors mere licensing agents for their parent companies. ${ }^{2}$ And five ${ }^{3}$ of these eight major companies are vertically integrated firms, owning a large number of affiliated theatres in addition to their production and distribution facilities. Consolidation in the industry has likewise taken place through the formation of chains of unaffiliated theatres. The great majority of theatres, however, have remained independent of large chains and unaffiliated with any of the five major theatre-owning defendants.

In its complaint in the anti-trust suit the Government sought divorcement of exhibition from production interests. ${ }^{*}$ In the compromise consent decree, however, attack was centered chiefly on certain alleged monopolistic practices in the industry. ${ }^{6}$ The decree was consented to by only the five major theatre-

t The editors of the Law Jounval wish to express their thanks to Professor Wesley A. Sturges of the Yale Law School for making available his unpublished manuseript on the motion picture industry consent decree read as a Rosenthal Leeture at Northwestern University in November, 1941.

1. See, for the background of the suit and the terms of the decree, Comment (1941) 50 Yale L. J. 854; Bertrand, Evans, Blanchard, TieC Rep., The Mothon Pretere Industry-A Pattern of Control. Monograph 43 (1941).

2. See, for a description of this development, Complaint, United States v. Paramount, Inc., et al., Civil Action No. 87-273 (S. D. N. Y. 1938) §III.

3. Paramount Pictures, Inc., Loew's, Inc. (successor to Metro-Goldwyn-Mayer Corp.), Radio-Keith-Orpheum Corp., Warner Bros. Pictures, Inc., and Twentieth Century Fox Film Corp.

4. United States v. Paramount Pictures, Inc., ct al., Civil Action No. 87-273 (S. D. N. Y. 1940). See, for a description of other anti-trust suits concerning the motion picture industry, Whitman, Antitrust Cases Affecting the Distribution of Motion Pietures (1938) 7 FordHaM L. Rev. 189.

5. Consent Decree, United States v. Paramount Pictures, Inc., ct al., Civil Action No. 87-273 (S. D. N. Y., Nov. 20, 1940) (hereinafter referred to as the Consent Deeree).

6. The present decree goes further than any previous effort of the Anti-trust Division in imposing positive methods of competition upon an industry, although no "code uf fair competition" in the N. R. A. sense has been established. The nearest previous equivalents of an overall "code" are probably the "Auto Finance Decrees." United States v. Ford, Civil Action No. 8 (N. D. Ind. 1938); United States v. Chrysler, Civil Action No. 9 (N. D, Ind. 1938). See Isenbergh and Rubin, Antitrust Enforcenent Through 
owning defendants; the "Little Three", ${ }^{7}$ owning no theatres, allowed the suit against themselves to continue since many of the Government's complaints were not applicable to them and since they were less concerned about the threat of divorcement. The industry practices dealt with in the decree werc chiefly of two kinds, restrictions on selling and abuses built on "run" and "clearance" provisions regulating showing. It had been the custom previous to the decree for major producers, some of whose product is necessary for" the survival of any theatre, to sell their pictures "blind" to exhibitors, in advance of production. Furthermore, the pictures were sold in "blocks", often containing as many as fifty films, covering all or almost all the output of the producer for the following season. The exhibitor buying pictures "blind" had little knowledge of their merits beyond what they could gather from proposed production schedules. And if the exhibitor bought any of the almost essential output of one of the major producers, "block booking" operated to force him to purchase all or almost all the yearly output of that particular major. It also tended to reduce competition from the independent producers of cheaper pictures whose chief bargaining point was the lower cost of their product. Likewise under "block booking" the stronger exlhibitors secured unfair competitive advantages such as the privilege, withheld from weaker competitors, of cancellation of a certain percent of the "book" and the chance to "overbuy" - that is to lease more pictures for the following year than could be used. This deprived competitors of access to quality production.

In dealing with selling restrictions Section III of the consent decree forbids sales except after a trade showing, and Section IV(a) prohibits sales in blocks of more than five. Section IV(b) proscribes "forcing", i.c., conditioning the sale of a feature picture on the purchase of shorts or westerns. Sections III and IV(a) were to be of no effect after June 1, 1942 if prior to that date a decree had not been entered against the "Little Three" requiring them to trade-show pictures and limiting the number in their "blocks."

The second general type of alleged monopolistic practice dealt with in the decree concerned "run" and "clearance" provisions governing the showing of pictures. Distributors have classified theatres into "runs", theoretically on the basis of their revenue producing capacity and other valid commercial considerations such as credit standing. Pictures are first shown in a given locality in the first-run theatres. ${ }^{0}$ They are then passed on to subsequent run theatres there to be shown presumably at reduced rates. To protect the

Consent Decrees (1940) 53 HARv. L. Rev. 386, 395 et seq.; Comment (1941) 50 Yale L. J. 854, 858 .

7. Columbia Pictures Corp., Universal Pictures Co. and United Artists Corporation. The last is, strictly speaking, a distributing company for a group of smaller producers.

8. Section XII of the Consent Decree. See page 1178 infra.

9. The term "zoning" was adopted to designate the area over which clearance was effective. The theatre first showing films in a zone is known as the first-run theatre. Bertrand, Evans, Blanchard, op. cit. supra note 1 , at 40. 
position of the higher-priced, first-run theatres, a certain "clearance"10 time between the two showings is permitted to elapse in accordance with provisions in the distributor-exhibitor contracts.

In attacking the alleged discriminatory practices resulting from abuse of "run" and "clearance" provisions, Section VI of the decree sharply limits the power of distributors to refuse exhibitors the grant of some run. Section $\mathrm{X}$ provides that, where in the allocation of runs an inferior chain theatre has been favored over a superior independent, there can be a reclassification of the run ranking of the two theatres. Under Section VIII where a distributor has granted unreasonable clearance to one theatre over another, the latter may have the unreasonable clearance reduced. These provisions in the decree are to continue in effect regardless of the outcome of the suit against the "Little Three."

In addition to the sections concerning selling restrictions and abuses built on "run" and "clearance", the decree contains a variety of other provisions. In an attempt to limit the buying power of large theatre circuits - affiliated and chain - Section V limits group licensing to theatres located in one exchange district. And harking back to the original objective of divorcement, Section XI requires, in qualified fashion, that the defendants not embark on any general program of acquiring new theatre holdings during the three years after the effective date of the decree.

Of great significance in the evolution of anti-trust techniques was the substitution of mandatory arbitration for cumbersome contempt procedures ${ }^{11}$ as the primary method of enforcing parts of the decree. Consenting distributors have bound themselves to arbitrate alleged violations of these seetions, and the charges can be brought by exhibitors who themselves are not parties to the decree. The arbitration proceedings talie place before tribunals set up by the American Arbitration Association, and there is a right of appeal to an Appeal Board. Thus, in place of the contempt procedure normally used in enforcing anti-trust injunctions there has been set up a relatively inexpensive framework which can readily be set in motion by the interests previously victimized. The operation of the decree serves therefore as a yardstick in determining the applicability of similar anti-trust techniques in other situations.

\section{Substantive Operation}

The provisions in the decree relating to selling restrictions, Sections III and IV, have been in operation since September 1, 1941.12 Section III

10. Clearance, as defined in the decree, is the period of time, fixed by agreement between a distributor and an exhibitor, prior to the expiration of which a feature licensed for prior exhibition in a theatre may not be exhibited in another theatre or theatres. Consent Decree, \$VIII.

11. See Hamilton, $A$ Judicial Process for Industry (1941) 5 ARs. J. 50 ; HAsmron, TNEC Rep., ANtrTrust in Action, Aionograph 16 (1940) 92.

12. Because, at the time the decree was entered, pictures for the selling season then current had already been contracted for, the provisions relating to trade showing and 
concerning "blind selling" and presumably enforceable by court action rather than by arbitration has not yet been litigated. Section IV prohibiting "forcing" and block booking in units greater than five has been involved in arbitration proceedings but once. ${ }^{13}$ Failure of the Government to impose similar limitations on "blind selling" and block booking in its suit against the "Little Three" has by the terms of the consent clecree voided the application of Sections III and IV(a) to the five consenting majors. ${ }^{14}$ Thus, these selling provisions of the decree have become a dead letter in the industry. ${ }^{15}$ The question of the shortcomings of the now invalid selling provisions and the desirability of new provisions is raised, however, by a so-called united effort within the industry to reach some compromise satisfactory to the various interests involved and to the Government.

Even before the consent decree was adopted independent exhibitors in a hearing before the court objected almost unanimously to the selling provisions. ${ }^{10}$ Among their objections was the complaint that selling in blocks of five destroyed the assurance of a steady flow of feature productions at known cost which they had under wholesale block booking. The exhibitors had principally objected only to the compulsory nature of the block booking system $^{17}$ which had forced them to take a producer's whole line with little privilege of cancellation. Furthermore, the exhibitors contended, licensing in blocks of five would mean that distributors would give no cancellation privileges from the book to weaker independent theatre operators.

The independent exhibitors now contend that the first six months of the decree's operation have borne out their prediction since, according to exhibitor reports, they "are experiencing one of the blackest years in their history." 18 Their chief complaint is an allegedly exorbitant rise in the price of film rentals without appreciable improvement in the quality of new productions. The distributors, conversely, have enjoyed a prosperous year ${ }^{10}$ and appear pleased with the decree's selling provisions. Apparently, under

"block booking" were not to become effective until the opening of the new selling season on Sept. 1, 1941.

13. Section IV has been involved once in combination with §VIII. Sec note 61 infra.

14. Communication to Yale Law Journal from Thurman Arnold, Assistant Attorney General in charge of the Anti-trust Division, Mar. 26, 1942.

15. However, since the major part of the current selling season, beginning Scptember 1,1941 , has gone by, there probably will be at least no immediate return to block booking as "blind selling" on the scale that existed before.

16. On Nov. 14, 1940, before the consent decree was entered, a formal hearing on it was held by the court. Representatives of virtually every important exhibitor association in the industry and of the three non-consenting defendants expressed opposition to the decree. Bertrand, Evans, Blanchard, op. cit. supra note 1, at 76. See (Nov. 20, 1940). See (Nov. 20, 1940) 140 VARIETX 4.

17. Bertrand, Evans, Blanchard, op. cit. supra note 1 , at 24.

18. Annual Report of the Chairman of the Board, Allied States Association of Motion Picture Exhibitors, Jan. 22, 1942, at 1-3; N. Y. Times, April 19, 1942, $\$ 8$, p. 4, col. 4.

19. Ibid.; N. Y. Times, Dec. 28, 1941, \$9, p. 5, col. 4 (financial report). 
the decree, most pictures have been sold in blocks of five rather than individually, and few cancellation privileges have been extended under the blocks of five plan. In addition, it is likely that despite the intent of Section IV the independent exhibitors are in no better position under the decree than they were before with regard to forcing of inferior features in the blocks of five ${ }^{20}$ and the forcing of shorts.

In its latest form the plan proposed by the united movement ${ }^{21}$ within the industry provides for quarterly licensing in groups of up to twelve features.22 At least five of the twelve would be trade-shown while the others would be reasonably well described. For all but the five trade-shown features a cancellation privilege of at least one film is assured all exhibitors. Those exhibitors in a weaker bargaining position would be permitted two cancellations per group.

While greater concessions might have been granted the exhibitors, the plan does assure them of some cancellation privilege, one of their chief objectives. However, some groups of exhibitors have rejected the proposal outright and have promulgated their own more liberal plans. ${ }^{23}$ In Minnesota independent exhibitor organizations succeeded in getting the legislature to pass a bill making mandatory the sale of films on a season's basis and providing exhibitors with a twenty percent cancellation right. ${ }^{21}$ Similar measures are being considered in other states, ${ }^{25}$ and if the Minnesota Act is upheld, 20

20. Thus before the decree the exhibitors may have received ten good pictures in a block of fifty. Now they may receive but one good picture in every block of five. The Department of Justice admits serious doubt that the decree's selling plan has enabled the small independent operator to compete with the large circuit in licensing films on any more favorable basis than under the old method of selling. Communication to Yaze Law Journal from Thurman Arnold, Assistant Attorney General in charge of Antitrust, Mar. 26, 1942.

21. A general meeting of producing and exhibiting companies was held in Chicago on Dec. 9, 10,11,1941, at which plans were considered for the formulation of an all industry congress to handle common problems. A revision of the method of distribution imposed by the decree was a chief aim. The conference was the first of its lind in the history of the industry and resulted in the organization of a national joint conference committee to foster industry-wide cooperation. See N. Y. Times, Dec. 9, 1941, p. 46, col. 5 ; N. Y. Times, Dec. 10, 1941, p. 34, col. 3 ; N. Y. Times, Dec. 11, 1941, p. 38, col. 4.

22. Final Proposed Selling Plan of the United Alotion Picture Industry, Sub-Committee on Trade Practices, April 1, 1942, in Box Office, April 11, 1942, at 6.

23. See Box Office, MIar. 21, 1942, at 10.

24. Act of Apr. 26, 1941, c. 460, §1; MAson's Mrnnesota Statutes (Supp. 1941) c. 21 AA. See N. Y. Times, May 4, 1941, $\$ 9$, p. 4, col. 1.

Upon application to it, the District Court, retaining jurisdiction of the consent decree, signed an order excusing distributors from complying in Mfinnesota with Sections III and IV of the decree. N. Y. Times, Nov. 4, 1941, p. 30, col. 2.

25. N. Y. Times, April 27, 1941, §9, p. 4, col. 1.

26. In dismissing a criminal action brought by the state charging violation of the statute, a lower state court in Minnesota held that the statute violated the dute process requirements of both the state constitution and the Federal Constitution. An appeal may be taken. See Box Office, April 18, 1942, at 6. 
they may well be passed. On the other hand, independent producers apparently liked the decree's selling provisions and oppose any return to a plan resembling wholesale block booking and "blind selling", ${ }^{27}$ The Government is likewise an interested party. Since this is a united scheme, for the industry to proceed without Governmental approval might well result in an anti-trust action against the plan as a combination in restraint of trade. Consequently, the various firms in the inclustry cooperating in the united scheme want the new provisions written into the decree. It is doubtful whether the Government will agree to the proposed plan. Certainly the public interest in the quality of its motion picture entertainment demands that there be as little "blind selling" as possible and that there be a close check by exhibitors responsive to community film judgments on the quality of the features purchased for exhibition in the locality.

The provisions in the decree, designed to remedy discriminations built on run and clearance, remain in effect despite the Government's temporary failure in its "Little Three" suit. Section VI of the decree, providing that "no distributor defendant shall refuse to license its pictures" to an exhibitor on some run, subject to certain conditions, became operative on November 20,1940 (the effective date of the decree). This section has been considered several times by the Appeal Board, and it would appear, from the Board's interpretations, that the Section is fulfilling its intended function of preventing arbitrary refusals of an exhibitor's request for at least some run.28

In its first decision, Matter of Rubin Frels, ${ }^{20}$ the Board interpreted the provision in Section VI that a license must be granted by the distributor on some run upon terms and conditions fixed by the distributor "which are not calculated to defeat the purpose of this section. . ." The Board maintained that an offer by a distributor may still constitute a refusal of a run if the offer is upon "obviously impossible terms" or is not "fair and reasonable". ${ }^{30}$ This construction is logical and in keeping with the intent of the decree. However, the Board's apparent disposition of the burden of proof on this point is open to serious question. In the case the complainant exhibitor had rejected the defendant distributor's offer of a run on the ground that it was not "an equitable deal". The Board dismissed the complaint, apparently on the ground that the distributor had offered some run and the exhibitor had failed to prove that this offer was one calculated to defent the purpose of the Section VI. ${ }^{31}$ Under this section, the distributor may rely upon his offer to the exhibitor as a defense to the complaint. It could

27. N. Y. Times, April 19, 1942, §8, p. 4, col. 3; N. Y. Times, May 3, 1942, § 8, p. 3 , col. 3 .

28. Dept. of Justice Release, Jan. 22, 1942, at 2.

29. Matter of Rubin Frels, Appeal Board of the Motion Picture Arbitration Tribunals No. 2, Aug. 21, 1941. (Hereinafter the citation for decisions of this Boatrd will be M. P. A. T.).

30. Id. at 5 .

31. Id. at 6 . 
therefore be argued that the burden of establishing the validity of this offer and all its terms and conditions as being fair and equitable might more justly be borne by the distributor who relies upon it for his defense. Moreover, it is the distributor who enjoys easiest access to the records and other information necessary to successfully carry this burden of proof.

In addition, the Board in the Frcls case indulged in a rather questionable dictum. It stated: "Of course once a distributor has tendered a license . . . [the exhibitor] obviously cannot thereafter complain that he has been refused a license." 32 The implication is untenable; need a consenting defendant make only one valid offer of a run to an exhibitor and earn total immunity from his demands thereafter? It would be regrettable if the Board forced exhibitors to forfeit all subsequent claims to any run under the section unless they accept the first valid offer of any run from a distributor. If the Board did not intend so to circumscribe the section, proper limitations should have been made explicit for the guidance of future arbitrations. If such a restrictive construction of the decree were intended, it might well support an application to the District Court for a more considered judgment.

In the second case to come before the Board under this section, ${ }^{23}$ the defendant, a distributor affiliated with one of the integrated companies, had refused the complainant any run on features previously exhibited in the defendant's own theatre. The sole defense was a contention that Section XVII nullified the provisions of Section VI with regard to a producer's pictures distributed to its own affiliated theatres. Section XVII provides that nothing in the decree shall be construed as a limitation of the right of a distributor to license exhibitions in its affiliated theatres upon any terms it wishes. The Board held that Section XVII could not be construed to permit the exclusive run policy claimed by the defendant, since one of the chief objectives of the decree (expressed in Section VI) was to enable independent exhibitors to obtain pictures. This seems to be a desirable result, for as the Board stated, the defendant's interpretation would have made useless a large part of the decree.

The Board in its third and most recent decision under Section VI further indicated its attitude toward this section. Although the arbitrator below had dismissed the complaint, the Board directed the defendant to offer its pictures for license to the complainant. A liberal attitude toward Section VI seems justified, as the Board has pointed out, ${ }^{35}$ since a distributor is afforded ample protection under the decree. The distributor need grant no run if it can show that its total film revenue in the particular competitive area will be thereby reduced. Indeed, the distributor is further protected, for, if

32. Id. at 4 .

33. Matter of John Koczak and Grace Koczak, M. P. A. T. No. 5, Oct. 10, 1941.

34. Matter of Louis Sosna, M. P. A. T. No. 15, Jan. 5, 1942.

35. Matter of John Koczak and Grace Koczak, M. P. A. T. No. 5, Oct. 10, 1941, at 4-5, 
experience should prove error in the first determination, the distributor may initiate another arbitration. ${ }^{36}$ If the arbitrator finds that the granting of a run in compliance with the award has had the effect of reducing the distributor's total film revenue in that area, he must vacate the first award.

There have been only six arbitration proceedings under Section $\mathrm{X}$ which provides that an independent theatre may prove itself entitled to a prior run over an inferior chain theatre unjustly favored. The infrequent resort to this seemingly important section since its effective date, September 1, 1941, may be primarily attributed to its over-technical requirements for suit ${ }^{37}$ and the limited character of its relief. ${ }^{38}$ Even an exhibitor who successfully proves his claim is not guaranteed any actual relief under the decree. Although the award may direct the inferior circuit theatre involved to negotiate thereafter for future licenses separate from its circuit, the distributor, if so inclined, need not alter the specific terms upon which he has been selling either theatre. In this event the exhibitor's only recourse is an anti-trust suit in which the previously won award can prove of only indirect and uncertain value. Relaxation of requirements for suit and provision for a more positive form of relief seem to be necessary if the section is to be of much use in accomplishing its purpose.

Section VIII dealing with discrimination through unreasonable clearance has been comparatively much used. ${ }^{30}$ A real concession to the exhibitor, ${ }^{40}$ the section rendered arbitrable his claim that the clearance under which his theatre was operating was unreasonable and gave the arbitrator power to fix the maximum future clearance between the theatres involved. However, a clause in Section VIII also provides that ". . . no award made in any arbitration under this Section shall restrict ... the distributor's right to license for any theatre any run which it desires to grant." The Board's interpretation, in its first few decisions, of this limitation on the arbitrator's authority to deal with runs, seriously restricted his power to eliminate unreasonable clearance ${ }^{41}$ and caused confusion not yet completely resolved.

36. This is the only occasion upon which a distributor may invoke arbitration pro ceedings under the decree. See Consent Decree, Section VI.

37. For example, only those exhibitors are permitted to arbitrate whose theatres were in existence at the date of entering the decree and who made a written demand for a better run prior to July 20,1940. For other restrictions see Consent Decree $\$ 10 \mathrm{~B}$. These restrictions have been defended on the grounds of preventing the swamping of the arbitration tribunals with complainants seeking valuable runs and of preventing a rush of new theatre building by exhibitors seeking to take runs away from established interests.

38. See Comment (1941) 50 YALE L. J. 854, 866-67; Annual Report of the Chairman of the Board, Allied States Association of Motion Picture Exhibitors, Jan. 22, 1942 , at 3.

39. One hundred forty-four cases have been initiated under this section?

40. See Comment (1941) 50 Yale L. J. 854, 864.

41. Dept. of Justice Release, Jan. 22, 1942, at 2-4. 
In its first decision under Section VIII ${ }^{42}$ the Board promulgated its definition of "run" as the time during which "the exhibitor is licensed to show the picture" 43 and of "clearance" as "the interval of waiting time", if any, between the conclusion of a showing in a prior run theatre and the commencement of the next showing in a subsequent run theatre. Thus, under this definition, the distributor in his contract of sale to exhibitor $X$ may agree to release a particular feature to $X$ on a specified date. And he may agree, in addition, that in licensing the same film to other theatres in competition with $X$, he will not allow them to begin showing until a specified time, say three weeks, has elapsed after termination of $X$ 's showing. If, on receiving the picture from the distributor, $X$ shows it for a week, he would then have a week's prior run over his competitors, and before these competitors could begin to play the feature, three weeks would have to elapse from the time $X$ stopped playing the film.

In its next decision under Section VIII the Board faced the necessity of using these concepts in applying the commands of the section relating to run and clearance. In Matter of $O$. WW. Lewis theatre $X$ had twenty-one days clearance over theatres $A, B$, and $C$, all in the same competitive area. The Board held the arbitrator lacked jurisdiction to postpone the release time for $B$ and $C$ so as to give $A$ seven days clearance over them, even though it could be proved that $X$ 's clearance over $B$ and $C$ was unreasonably short and even though the clearance arrangement made in the award was "a fair and equitable adjustment." As its first ground for the decision the Board interpreted the decree as authorizing the arbitrator only to reduce, not to increase clearances. This is seemingly a valid interpretation of the decree..$^{45}$ However, as an additional ground the Board stated that the effect of the award was to create a run in favor of $A$ over $B$ and $C$, something which was beyond the arbitrator's power even though the clearance eliminated thereby was unreasonable. Similarly, in Matter of Garbosets the complainant's first-run theatre in Athol, Massachusetts, and intervenor's theatres in Gardner, Massachusetts, were under like clearance in favor of Fitchburg. In affirming the arbitrator's dismissal of complainant's demand for a release on the same date as Fitchburg, the Board held that this "would have given the Athol theatres the same run as the Fitchburg theatres . . .

42. Matter of Ken Theatre Corporation, M. P. A. T. No. 1, June 11, 1941.

43. Compare 2 Iatter of William Pearl, M. P. A. T. No. 26, June 4, 1942, in which the Board apparently changed its definition to the time during which an exhibitor shoass a picture.

44. M. P. A. T. No. 7, Oct. 17, 1941.

45. However, this interpretation might likewise give rise to difficulties. Suppose in its contract with $\mathrm{X}$ a distributor guarantees $\mathrm{X}$ twenty-one days' clearance over $\mathrm{A}$, and in its contract with $A, A$ is guaranteed seven days over $B$. A then seeks to have the arbitrator reduce X's clearance over him to fourteen days. Could $B$ in intervening justifiably argue on the basis of the Lecris case that such an award was beyond the arbitrator's power since it would increase A's clearance over B?

46. M. P. A. T. No. 9, Oct. 31, 1941. 
and a run ahead of the Gardner theatres. Such an award is bcyond the powers of an arbitrator under Section VIII of the decree." ${ }^{47}$

Certainly it is possible to argue that to give Athol the same release date as Fitchburg creates for Athol a "run" over Gardner. On the other hand, it is difficult to see how such an award would within the terms of the consent decree "restrict . . . the distributor's right to license for any theatre any run it desires to grant." For if the distributor desired to keep Athol and Gardner on the same "availability date" he could, after the award, have reduced Fitchburg's clearance over Gardner to the clearance given Fitchburg over Athol.48

In Matter of Raritan Amusement Co., Inc., ${ }^{40}$ a later case, in a situation analogous to that in the Garbose case, the Board reached the opposite result apparently on the basis of the rationale suggested. Here, complainant's Playhouse Theatre at Raritan was under twenty days clearance to intervenor's theatre in Somerville. Somerville also enjoyed fourteen days clenrance over Manville from two distributor defendants and seven days from two other defendants. All the theatres were in the same competitive area. The Board sustained an arbitrator's award reducing Somerville's clearance over Raritan to seven days. In rejecting the contention that this reduction created for complainant a run prior to Manville, the Board said, "Manville has no run ahead of Raritan; nor has it any clearance over Raritan in any contract. Both are subject to clearance from Somerville. The reduction of this clearance does not restrict in any way a distributor's right, under Section VIII, to license Manville for a run ahead of Raritan, with or without clearance or Manville's right to negotiate for such a run." 50 Although this seems the more desirable result, it leaves the position of the Board uncertain.

The definition of run, adopted by the Board, as the time "during" which the picture is being shown leaves open the possibility that the distributor may legally nullify the "reduction of unreasonable clearance" provision in Section VIII by merely "milking" the run. This is accomplished by allowing a prior run theatre an unreasonably long period of run rather than an unreasonably long period of clearance. Then, even though the next subsequent exhibitor be allowed to play within twenty-four hours after the end of the prior run, he may still be greatly injured; and under Section VIII the arbitrator has no power to adjust the unreasonably long run period. While Section $\mathrm{X}$ offers some hope of adjusting this disparity, the inadequate character of that section has already been noted. On the other hand, if "run" had been defined by the Board as "starting date" alone, all theatres starting at time one would be on run one, and those (in the same competitive area)

47. Id. at 6 .

48. In the Lezvis case, however, the arbitrator in his award expressly granted $A$ seven days' clearance over B and C. This would seem to be clearly beyond his power.

49. M. P. A. T. No. 11, Nov. 28, 1941.

50. Id. at 4. 
who started at time two would be on run two regardless of whether time two is five days or five minutes later than time one. And this would be true even though the second run might start before the first one was terminated. Clearance would then comprise the allole period between the starting times including that period during which the feature is being shown in the prior run theatre. That playing period would then likewise be subject to reduction if found unreasonable by the arbitrator. Such a definitiun would eliminate the possibility for abuse by "milking" the run present under the Board's definition.

In addition to the confusion engendered by its stand on Section VIII concerning restrictions on abolition of unreasonable clearance, the Board seems to have limited unnecessarily the extent to which an arbitrator may reduce a period of clearance after having found it unreasonable."12 In Matter of Garbose 52 the Board held that the reduced period of waiting time "cannot be less than a day of twenty-four hours" when "the theatres involved are in the same competitive area." This holding seems at odds with the purpose of Section VIII to eliminate unreasonable clearance. Certainly, where the two theatres are not in the same competitive area the arbitrator may completely eliminate clearance between them..$^{53}$ And it is frequently the practice in the industry to have subsequent runs follow immediately the prior showing with no intervening clearance $;^{54}$ there is nothing in the decree which forbids fixing a five minute clearance.

It must be noted that the Board's more recent decisions under Section VIII have shown a marked liberalization of its views. ${ }^{55}$ For example, in its third decision ${ }^{56}$ the Board approved the act of the arbitrator in holding that he had no power to make an award which would adversely affect the interests of an exhibitor named in the complaint as having an unreasonable clearance over the complainant but who had deliberately foregone his opportunity to intervene. Under such an interpretation the decree could be nullified by any unaffiliated theatre complained against which chose to ignore the arbitration proceeding. Fortunately, however, in its twelfth opinion ${ }^{27}$ the Board, without explanation, appears to have reversed this holding. In that case, two duly notified interested theatres had not intervened and the arbitrator ruled "he could not consider the position or the

51. Dept. of Justice Release, Jan. 22, 1942, at 3.

52. M. P. A. T. No. 9, Oct. 31, 1941.

53. Matter of St. Lawrence Investors, Inc., M. P. A. T. No. 4A, Nov. 7, 1941.

54. See Motron Picture Herald, Jan. 3, 1942. The Board has likewise tended to indulge in de minimis perfectionism in working out applications of concepts such as clearance which must at best be rough approximations. See Dept. of Justice Release, Jan. 22,1942 , at 2-3.

55. Even the exhibitors have conceded this. Communication to Yale LAw Jour:ial. from the Allied States Association of Mfotion Picture Exhibitors, April 4, 1942.

56. Matter of Westway Theatre, Inc., M. P. A. T. No. 3, Sept. 22, 1941.

57. Matter of Esquire-Great Neck Corporation, M. P. A. T. No. 12, Dec. 5, 1941. 
rights and wrongs of these theatres." The Board held this error. This holding seems fully justified in view of the decree provisions which, recognizing that the real party in interest in a clearance proceeding under Section VIII is the exhibitor possessing the unreasonable clearance, give ample notice and opportunity to intervene to this exhibitor. Furthermore, in six out of the last seven appeals under Section VIII, the Board has in some respects gone further than the arbitrator in reducing or preventing the creation of unreasonable clearance. There can be no doubt that a liberalization of the terms of the section and the Board's consistent interpretation thereof is essential if the abuses alleged in the Government's petition are to be checked.

The Department of Justice openly recognizes that the section has for at substantial number of situations failed to provide adequate relief to the extent which the Sherman Act requires ${ }^{58}$ It will therefore recommend, at the conclusion of the test period, modification of the section in preference to continuance in its present form. Another desirable change would be some definite provision for a late-run exhibitor who is frequently injured more by having to follow an excessive number of affiliated theatres than by following any one of them by an excessive number of days. ${ }^{50}$ Nor is it clear that adequate remedy is assured in a situation such as the following. Exhibitor $A$ is under 7 days clearance to $Y ; Y$ is in turn under 21 days clearance to $Z$. Assume $Y$ 's clearance over $A$ is reasonable but the 28 day waiting period indirectly created between $A$ and $Z$ is onerous. $A$ should be empowered to attack as unreasonable the actual protection accorded $Z$ or in some manner to telescope the aggregate time required for a feature to reach his theatre.

Among the miscellaneous sections dealing neither with formal selling restrictions nor run and clearance abuses, Section V prohibits a distributor from licensing features under a single license to theatres located in more than one exchange district. The purpose of the section was to break up to some extent the powerful mass buying position of the large chains and groups of affiliated theatres. Presumably the smaller groups of independents would then be on a more equal bargaining level with the large chains.

A complete absence of claims under Section V cannot reflect the successful constriction of the purchasing power of larger nationwide circuits. Its inactivity is more reasonably indicative of the inadequate character of the relief and incentive offered a potential complainant. The offending distributor is at most obliged to pay a fine of $\$ 500$ into an overhead fund for maintenance of the arbitration facilities, an award of no benefit to the exhibitor. The exhibitor professes a fear of filing these complaints against a distributor with whom he must continue to deal and who is in a position

58. Dept. of Justice Release, Jan. 22, 1942, at 4.

59. Id. at 3-4. 
to retaliate by "selling away to competitors" and raising film rentals. 60 If exhibitors are unwilling to testify in the arbitration tribunals, they probably would be equally unwilling to do so in court, and under these circumstances it is difficult to perceive how the Government can help them. But while his hesitancy is in the long run to his disadvantage, it is unrealistic to expect an independent exhibitor to hazard the policing of this section in return for the little concrete relief presently offered.

For similar reasons Section IX remains practically undisturbed. ${ }^{61}$ This section purported to prevent a distributor's withlıolding from one exhibitor prints available in its exchange for the purpose of giving another exhibitor, usually competing on the same run, a prior playing date not in the contract. However, under Section IX when too few prints are available at the exchange for the date desired by both theatres, the distributor is left to his discretion. Moreover, it must be found that the distributor has pursucd a policy of withholding these prints; the award directs him to discontimuc this policy. An even more serious objection is the exhibitors' contention that this section missed the target completely in that prints are not usually withheld for the purpose of creating a play date not specified in the license. ${ }^{62}$ Prints are withheld, they contend, in order to grant to a prior run theatre clcarance not specified in its contract. If this is true, an additional section is imperative if the discrimination is to be eliminated.

Section VII would subject to arbitration an exhibitor's demand for cancellation of a feature on the ground it was found to be generally offensive to his locality on moral, religious or racial grounds. The total absence of complaints under this section, in operation over a year, probably indicates some corresponding scarcity of offensive releases. ${ }^{03}$ The influence of the decree in this regard is conjectural. The true effectiveness of the section will not be shown until modification is made in its present requirement that an exhibitor notify the distributor of his objections within ten days after the final license negotiation. Actually, the feature's first public showing may not have been held until well over ten days after such negotiation. Local reaction cannot be accurately ascertained until that time. An exhibitor plan to change this limit upon the time of notice to "within a reasonable amount of time after the contract is approved" appears far more logical and should be adopted.

60. Communication to Yale Law Journal from the Allied States Association of Mrotion Picture Exhibitors, April 4, 1942.

61. This section has been invoked in two cases in which the more active Section VIII (clearance) was also invoked. It was probably the latter section which provided ineentive for the institution of suit.

62. Communication to YALE LAw Journal from the Allied States Assaciation of Mrotion Picture Exhibitors, April 4, 1942.

63. Exhibitors feel that there have not been many offensive pictures released in recent years. Communication to Yale Law Journal from the Allied States Asscciation of Motion Picture Exhibitors, April 4, 1942. 
Finally, Section XI prohibits in qualified fashion a general program of theatre expansion by the majors. This provision is the closest approach in the decree to the problem of divorcement, which, as stated above, was the original aim of the anti-trust suit. It was weakly conceived and has been similarly weak in execution. Although it provides that for a period of three years no consenting defendant shall enter upon a general program of expanding its theatre holdings, reports made to the Department of Justice indicate that defendants have acquired interests in approximately 150 theatres. ${ }^{64}$ The Department alleges that this exceeds by more than 100 the number of theatre interests disposed of by them since the entry of the decree. $^{65}$ Some of these acquisitions have been in towns where the defendants held no previous interests; in others, the public is now forced to attend one of the defendant's theatres or forego motion picture entertainment. It is further alleged that some of these acquisitions have been made to prevent the prosecution of complaints by competitors through legal proceedings or arbitration. ${ }^{66}$ However, even these abuses may perhaps be protected under a "weasel" clause which permits acquisitions by a defendant "to protect its investment or its competitive position or for ordinary purposes of its business." The Government, aware of this weakness, has begun suit to test the section and petitions have been filed against Paramount ${ }^{07}$ and Twentieth Century-Fox ${ }^{68}$ who appear to have acquired interests in 87 and 40 theatres respectively and disposed of 21 and $10 .^{69}$ The petitions allege all the violations enumerated above and pray the court to order each defendant to divest itself of all interests acquired after November 20, 1940 and any further relief the court may deem proper. It must be recalled that the Government's suit alleged as necessary divorcement of. affiliated theatres from production interests. ${ }^{70}$ Under Section IX the Government is to forego divorcement action and the defendants are to forego an expansion program for three years. The Government maintains it has not relinquished the idea of complete

64. Dept. of Justice Release, Jan. 22, 1942, at 5.

65. Ibid.

66. Id. at 5-6.

67. United States v. Paramount Pictures, Inc., Civil Action No. 87-273 (S. D. N. Y. Jan. 29, 1942).

68. United States v. Twentieth Century-Fox Film Corporation and National Theatres Corporation, Civil Action No. 87-273 (S. D. N. Y. Jan. 29, 1942).

69. Petition, United States v. Paramount Pictures, Inc., Civil Action No. 87-273 (S. D. N. Y. Jan. 29, 1942) at 4-8; Petition, United States v. Twentieth Century-Fox Film Corporation and National Theatres Corporation, Civil Action No. 87-273 (S. D. N. Y. Jan. 29, 1942) at 4-6.

70. The original complaint attacked the large scale vertical integration of production and exhibition as the principal cause of restraint and monopoly in the industry, and prayed for divorcement of exhibition from production as the major form of relief. Complaint, United States v. Paramount Pictures, Inc., et al., Civil Action No. 87-273 (S. D. N. Y. 1938). See especially 133, 173-98; 222-26, and Prayer, 4-6. See Comment (1941) 50 YaLE L. J. 854-58. 
divorcement ${ }^{; 1}$ very likely the outcome of the present trial will largely determine the Government's future course.

\section{Procedural Operation}

Procedurally, the decree aimed to eliminate the expensive and time-eonsuming litigation generally attendant upon the enforcement of consent decrees. $^{72}$ To this end, the impartial American .1rbitration .Association was appointed to set up and administer a system for arbitrating exhibitor claims of distributors' violations of the decree. ${ }^{73}$ That the physical equipment, personnel, forms and other facilities provided by the administrator have lieen eminently satisfactory, there can be no doubt. ${ }^{74}$ By February 1, 1941, 72 days after the entry of the decree, there had been established 31 nation-wide Motion Picture Arbitration Tribunals in which exhibitor Demands for Arbitration might be filed. ${ }^{75}$

The number of proceedings initiated by complaining exhibitors, their conduct and results, will be basic factors in analyzing the decree's operation. From the opening of the Tribunals through March 31, 1942, there have been initiated in thirty of the thirty-one tribunals a total of 199 claims. $^{76}$ Of these, 95 were carried to awards, 47 settled or withdrawn, while 57 awards are pending. The complaining exhibitor has been successful in to of the awards, the defending distributor in 49. With insignificant exception, only three of the seven arbitrable sections of the decree have been invoked..$^{77}$

Parties dissatisfied with the decree contend that the number of claims initiated thus far is small enough to indicate an eventual failure of the system. But in fact under few statutes are so many cases brought within a year of its effective date. In addition, the availability of the machinery has concededly induced many settlements which made resort to the tribunals unnecessary: ${ }^{78}$ It is further alleged that a previously large number of exhibitor grievances

71. Dept. of Justice Release, Jan. 22, 1942, at 6.

72. Hannilton, TNEC Rep., Axtitrust in Action. Monograph 16 (1940) 92.

73. Consent Decree $\$ 22$. See, for a description of the American Arbitration Association, Eastman, Foreword (1937) 1 ARB. J. 1; Odlum, The National System of the American Arbitration Association (1937) 1 ARB. J. 6.

74. Dept. of Justice Release, Jan. 22, 1942, at 1.

75. Consent Decree $\$ 22$ provides for a tribunal in each city in which three or more distributor defendants maintain exchanges.

76. These statistics and those which follow have been compiled from records at the central office of the American Arbitration Association, 9 Rockefeller Plaza, Jew Yorl: City.

77. The three most active sections have been $\$ \$$ VIII (clearance) $14 t$ cases, VI (sume run) 30 cases and $X$ (designated run) 6 cases. The inactive sections have been $\mathrm{IV}, \mathrm{V}$, VII and IX. See Comment (1941) 50 YALE L. J. 854, 859-64, 864-68.

78. Communication to Yale Law Journal from Thurman Amold, Assistant Attorney General in charge of Anti-trust, Mar. 26, 1942. Dept. of Justice Release, Jan. 22, 1942 , at 5. 
continually submitted to the Department of Justice as well as the number of exhibitor anti-trust suits against distributors has been substantially reduced..$^{70}$

For a program designed to eliminate time-consuming court litigation, the record thus far is not over-encouraging. In the 95 cases carried to awards, there has elapsed an average of 105 days between the filing of a Demand and the arbitrator's award. ${ }^{80}$ The shortest period was 27 days, the longest, 371 ; the average actual hearing time was two days. Although the arbitrations have consumed less time than the usual court litigation, various improvements must still be made. The maximum time under the decree for bringing a caluse before an arbitrator after filing the demand is 27 days. ${ }^{81}$ The lapse of longer periods is due solely to postponements for the convenience of parties and counsel. It appears that where an exhibitor has suffered so long the types of abuse complained of, ultimate relief, though unnecessarily delayed, may still seem to him quite satisfactory. Experience may demonstrate that the time prescribed for notice, re-notice and selection of the arbitrator ${ }^{82}$ can be somewhat shortened without harm. The same may be said regarding convenience of counsel. Greater need of modification is found in the present method of procuring simple evidence through tedious testimony and cross-examination. Conferences could be arranged through which parties might agree upon preparation of certain documentary proof to be submitted as stipulations at the hearing. ${ }^{83}$ The Appeal Board has also suggested ${ }^{84}$ that exhibitors confine their proof to those factors which the arbitrator is required to consider. ${ }^{85}$ Moreover, in many cases certain of these factors are developed to unnecessary lengths. ${ }^{86}$ It is also unfortunate that the comments of counsel often fill more space in the transcript than the testimony of witnesses. ${ }^{87}$ The arbi-

79. (Nov. 8, 1941) 146 Motion Picture Herald 27.

80. See note 76 supra.

81. See Rules of Arbitration and Appeals Pursuant to Sub-Division 6 of Section XXII of the Decree and accompanying the Decree (hereinnfter referred to as Rules of Arbitration and Appeals).

82. Rules of Arbitration and Appeals, $\S$ I and III.

83. See Warburg, First Quarterly Report of the Motion Picture Arbitration Tribunals (1941) 5 ARB. J. 185, 187. The Washington Tribunal originally tried this plan with promising success. The procedure saved the time, not only of the arbitrators and the parties, but of the several witnesses who would have been called upon to bring documents from their offices and remain at the hearing while the data sought were obtained from them by testimony and cross-examination.

84. See, Matter of Fred W. Rowlands, M. P. A. T. No. 13, Dec. 26, 1941, at 8.

85. Section VIII of the Consent Decree prescribes seven specific factors (c.g., historical development of clearance in the area, admission prices, character and location, etc.) which the arbitrator must weigh in determining reasonable clearance.

86. Records of cases show, for example, that the testimony regarding historical development of clearance in the particular area wherein the theatres involved are located is unnecessarily prolonged. Only in exceptional cases when there have been violent changes in clearance schedules need this factor be so painstakingly developed.

87. See Matter of St. Lawrence Investors, Inc., M. P. A. T. No. 4A, Nov. 7, 1941, at 5 . 
trator, by judicious handling of the proceeding, may to some extent control these latter aspects. But only sincere efforts by parties and counsel can effect the substantial reduction in time which had been anticipated.

The cost factor, another important criterion, is not so easily appraised for want of complete data. ${ }^{88}$ However, the per case costs of arbitration, in many cases divided between the parties by the arbitrator's assessment, appear to be as follows:

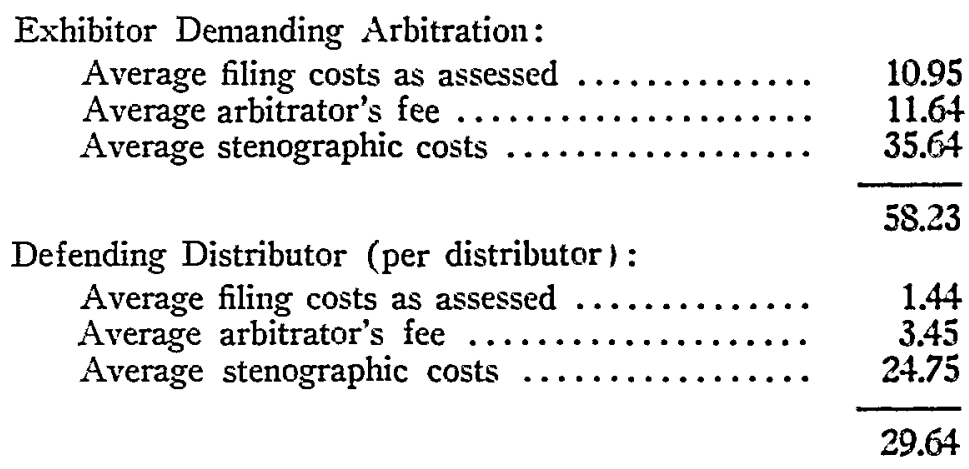

It is important to note that these figures do not include costs for counsel. ${ }^{89}$ While the principal expense appears to be the stenographic costs, it is certain that attorney's fees are at least of equal proportion. Neither of these expenditures lies within the control of the decree or the Administrator. Higher average costs have fallen to the exhibitor complainants hecause in almost all cases there were a number of defendants who shared the assessed costs while the complainant bears his share alone. ${ }^{30}$ Although the decree would permit an arbitrator's fee of $\$ 50$ per day, ${ }^{01}$ by the administrator's determination the arbitrator receives only an honorarium of $\$ 10$ for each day of hearing. ${ }^{2}$ Even this token, although commendable, is not essential and may be discontinued without objection. A reduction in the length of proceedings will reduce the arbitrator's fee, may reduce counsel's fee and is the only method of restricting stenographic costs.

The foregoing averages do not include the cost of maintenance of facilities which is borne entirely by the distributors. ${ }^{93}$ First year operations, for which

88. See note 76 stupra.

89. Retained by all parties in approximately 90\% of the cases. Warburg, Sccond and Third Quarterly Reports of the Motion Picture Arbitration Tribunals (1941) 5 Arn. J. $286,290$.

90. Ibid.

91. Rules of Aribtration and Appeals, Section XI.

92. See Warburg, First Quarterly Report of the Motion Picture Arbitralion Tribunals (1941) 5 ARB. J. 185, 188.

93. Consent Decree, $\S X X I I$, Sub-Division 8. Each consenting defendant is assessed by the administrator in amounts proportionate to their respective yearly gross receipts from licenses for exhibition. The filing fees and the fines imposed under $\S \S \mathrm{IV}$ and $\mathrm{V}$ of the decree also go into this fund. 
the decree provided $\$ 490,000,{ }^{04}$ were administered at an actual cost of $\$ 300,000 .^{95}$ The Budget Committee named by the court has requested, for operations in $1942, \$ 294,000$, plus a $\$ 25,000$ contingency fund, ${ }^{\text {oc }}$ although the decree would permit an expenditure of $\$ 450,000 .^{87}$ It may be contended that $\$ 300,000$ is still a high price for less than 150 arbitrations per year. Probably the industry has not received full value for the over-all costs, notwithstanding their reasonableness. An improved decree would achieve greater results for the same expenditure. Conversely, if and when the machinery successfully enough adjusts the internal disputes of the industry, it will have assured self-regulation at a trifling investment.

Regarding the panel of 1,171 persons available as arbitrators, ${ }^{08}$ there has been much praise and little criticism.99 The Department of Justice does believe that the arbitrators' unfamiliarity with the inclustry, prescribed by the decree, ${ }^{100}$ has "given added weight to the superior presentation" of the distributors' cases. ${ }^{101}$ It is alleged that the distributors enjoy an important advantage over the exhibitors in that the former have access to legal talent which is more fully acquainted with the industry's technical problems. Uncloubtedly expert knowledge in an arbitrator would expedite full and rapid comprehension, sifting and weighing of proof. ${ }^{102}$ But the desiderata of impartial clecision and preclusion of valid suspicion that either party dominates the decrec have been admittedly secured in a manner which justifies retention of the requirement. ${ }^{103}$ Moreover, the problem of assuring the independent exhibitor expert presentation of his case is one which national and regional associations of exhibitors can solve. A final suggestion may be made regarding the form of the arbitrator's award. Certain sections specifically enumeratc matters which the arbitrator shall consider and the findings he shall make in determining the award. ${ }^{104}$ There is no requirement that his considerations or findings be specified in the award and the Appeal Board has often complained that the arbitrator does not state the reasons underlying his decision. ${ }^{105}$ The requirement of a written elucidation of these consiclerations would immeasurably aid an Appeal Board unfamiliar with these local data.

94. Consent Decree, $\S$ XXII, Sub-Division 5.

95. N. Y. Times, Nov. 3, 1941, p. 17, col. 2; N. Y. Times, Nov. 16, 1941, $\$ 9$, p. 5, col. 5 .

96. N. Y. Times, Nov. $16,1941, \S 9$, p. 5, col. 5.

97. Consent Decree, $\S$ XXII, Sub-Division 5 .

98. Records of the American Arbitration Association, 9 Rockefeller Plaza, New York: City.

99. See Motion Picture Herald, Jan. 3, 1942, which severely criticizes the decreo but praises the calibre of the arbitrators selected and the efficiency of the administrator.

100. Rules of Arbitration and Appeals, Section II.

101. Dept. of Justice Release, Jan. 22, 1942, at 1.

102. Krllor, Arbitration in Action (1941) 21-22, 100.

103. See note 100 supra.

104. See note 85 sipra.

105. See Matter of Main Theatre, Inc., M. P. A. T. No. 14, Dec. 26, 1941, at 2-3, and Matter of Lucien Descoteaux, M. P. A. T. No. 6, Oct. 17, 1941, at 4-5. 
A three man Appeal Board appointed by the court has jurisdiction to determine appeals upon any ground from the arbitrator's award. ${ }^{106}$ The Board has utilized its powers to affirm, modify, and reverse these awards and to remand for further proceedings in accordance with its decision. As does a court, the Board now cites and relies upon its former decisions as binding precedents ${ }^{107}$ and has attempted to round out, elaborate and give color to the substantive and procedural provisions of the decree. ${ }^{103}$ Thus far there has been filed a total of 30 appeals. ${ }^{100}$ The Board has rendered 20 decisions, 2 appeals have been withdrawn, and 8 decisions are pending. Of the 20 decisions rendered by the Board, 7 have, broadly speaking, modified the award of the arbitrator, 7 have reversed the award, and 6 have affirmed the findings below. Ten decisions have been in favor of the exhibitor complainant and 10 in favor of the defending distributor. The period between the arbitrator's award and the decision on appeal averaged 97 days; an average of 200 days elapsed between the filing of the Demand and the Appeal Board's decision. ${ }^{110}$ It should be noted that a party may appeal not later than 20 day's after the filing of the arbitrator's award. ${ }^{111}$ Records indicate that in most instances the appeal was filed on the last day. Within 30 days after the filing of the Notice of Appeal, copies of briefs are exchanged by parties; ten days are allowed to file return briefs. Hence, a total of 60 days is allowed the parties actually to bring the cause before the Board, ${ }^{112}$ and in most cases the full time is taken. There appears to be at least one expedient method of reducing this time. Parties are at present required to obtain the Board's permission for oral argument. ${ }^{113}$ There can be little reason for a denial of this request. The Board's work to date has not been burdensome, and argument by competent parties, especially as it relates to local conditions and practices, may be of genuine assistance to the Board. Elimination of the petition for oral argument and substitution of automatic permission therefor could reduce by 10 days the time on appeal. Costs on appeal other than the $\$ 25$ filing fee are not accurately available. ${ }^{114}$

106. Consent Decree, $\S X X I I$, Sub-Division 7; Rules of Arbitration and Appeals, $\$ \S \mathrm{XIV}-\mathrm{XIX}$.

107. See Míatter of St. Lawrence Investors, Inc., M. P. A. T. No. 4A, Nov. 7, 1941, at 4, and Matter of Esquire-Great Neck Corporation, M. P. A. T. No. 12, Dec. 5, 1941, at 10 .

108. See, for example, Matter of Ken Theatre Corporation, MI. P. A. T. No. 1, June 11,1941 , at $5-7$.

109. From the records of the American Arbitration Association through Mar. 31, 1942.

110. See note 76 supra.

111. Rules of Arbitration and Appeals, $\S$ XIV.

112. Rules of Arbitration and Appeals, $\S$ XVI.

113. Ibid.

114. These costs would, however, include the expense of printing the record and fees of attorneys where they are used. 


\section{CONCLUSION}

The first stages in the operation of the decree have shown that a liberal interpretation of it by the arbitration tribunals is a prerequisite to the achievement of its avowed objectives. Arbitration has often been stuccessfully applied as a method of settling internal disputes of an industry and affording it a measure of self-regulation.115 But the arbitration here imposed is unique, since its substantive and procedural rules are expressly set forth in a single instrument analogous to a statute. ${ }^{110}$ This necessity for the tribunal to interpret a law as well as to consider a fact situation has rigidified to some extent the customarily flexible arbitration proceeding. Nevertheless, with slight modification $^{117}$ a procedural mechanism efficient to the extent the parties chose to make it so should be available for adjustment of disputes. To date completely effective use of arbitration under the decree has been hampered by exhibitor non-cooperation resulting from their hostility to parts of the decree. ${ }^{118}$ Removal of restrictions on initiation of complaints and provision for more adequate awards should remedy this in part. The procedural machinery for arbitration apparently represents an advance over contempt methods for policing anti-trust decrees although as yet its fullest possible benefits probably have not been realized.

With the broad limitations inherent in the decree it is still an open question whether under it the advantages of competitive conditions can be restored to the industry. The decree has been more or less effective in dealing with some abuses such as unreasonable clearance and refusal to grant a run on some terms. And it has stimulated a movement within the industry look:ing toward self-regulation of some of its abuses. But by its terms the decree effected no fundamental change in the competitive structure of the industry; rather it tended to freeze the present pattern of competition. Most of the

115. See Sturges, Kent, Grossman, Nordlinger, Popkin, Jacobson, Fraenkel, Isaacs, Robinson, Deller, Nussbaum and Everett, $A$ Sympositum on Commercial, Industrial and International Arbitration (1940) 17 N. Y. U. L. Q. Rev. 495; Kellor, Arbitrdtion iN ACTION (1941) 3-15.

See, for history and evaluation of consent decrees in antitrust enforcement, Isenbergh and Rubin, Antitrust Enforcement Through Consent Decrees (1940) 53 Harv. L. Rev. 386; Katz, The Consent Decree in Antitrust Administration (1940) 53 HaRv. L. REv. 415.

116. See Kellor, Arbitration in Action (1941) 206-07.

117. On the general problem of modification of consent decrees in antitrust regulation see Donovan and McAllister, Consent Decrees in the Enforcement of Fedcral AntiTrust Law (1933) 46 HaRv. L. Rev. 885.

118. Since exhibitor complaints to the Department of Justice provided the immediate incentive for the Government suit, they were at first known as the "beneficiaries" of the decree. Nevertheless, unaffiliated exhibitor interests strenuously oppased the entry of the decree. See note 16 supra. Although after its entry, many exhibitor associations promised to cooperate, it is doubtful if any whole-hearted effort was cver made. But $c f$. Annual Report of the Chairman of the Board, Allied States Association of Motion Picture Exhibitors, Jan. 22, 1942, at 1-3. 
abuses alleged in the original petition have remained untouched. ${ }^{110}$ Thus, the monopoly control resulting from the majors' ownership of most of the important first-run theatres still exists. Likewise, no effective steps have been taken to deal with the majors' cooperation among themselves and the similarity of their actions with regard to independents. In addition, there remains the threat of abusive practices arising from the power of unaffiliated chains of theatres. ${ }^{120}$ As the decree now stands, the many escape clauses available to the majors make it unlikely that any effective change in the competitive situation will be achieved by its workings. While the quality of entertainment may to some extent have improved since the decree became effective, ${ }^{121}$ the price of admission and the powers of the local communities to select their pictures remain much the same. Divorcement of exhibition from production and distribution interests still remains as a possibility, although it is not available to the Government until three years after entry of the consent decree. Likewise, Congressional action is possible if the Sherman Act appears incapable of offering a remedy for the situation. ${ }^{122}$ Perhaps, by the end of the Government's enforced inactivity, enough time will have elapsed to allow, concerning the decree, consummation of a judgment which at present must remain only tentative.

119. See complaint, United States v. Paramount Pictures, Inc, ef al., Civil Action No. 87-273 (S. D. N. Y. 1938).

120. See Comment (1941) 50 Yale L. J. 854-56. At about the time it brought the divorcement action, the Government also brought suit to dissolve some of the larger unaffiliated theater circuits. A temporary agreement has recently been reached by the Government and the defendants in one of these suits, United States v. Schine Cluain Theaters, Civil Action No. 223 (W. D. N. Y. 1939). In this suit the Government alleged that the Schine circuit, a large unaffiliated chain of theaters, hasd conspired with various of the major producers to deprive independent, competing exhibitors of access to films and drive them out of business. The Government in its suit sought dissolution of the circuit. By the terms of the temporary agreement the circuit is not to acquire theaters in specified localities for two years; the circuit is to divest itself of sixtcen theaters acquired since 1939; and trial is postponed until May 19, 1944. See (June 13, 1942) 147 Motion Picture Herald 18.

121. While some exhibitors concede some improvement in the quality of motion pictures, they attribute it to nothing more than normal progress of the industry. See N. Y. Times, Apr. 19, 1942, \& 8, p. 4, col. 3 .

122. The Motion Picture Research Council, for example, has contended that the present Sherman Antitrust Law is totally inadequate to afford local communities the power to select their own films. It urges prompt passage of the Nedy bill, a proposed Congressional measure, which would permit exhibitors a greater power of cancellation. See N. Y. Times, Oct. 31, 1940, p. 9, col. 4; Bertrand, Evans, Blascenard, op. cil. sisfrco note 1 , at 76 . 